\title{
Úvaha nad knihou Domestic Judicial Treatment of European Court of Human Rights Case Law: Beyond Compliance
}

\section{Reflection on the Book Domestic Judicial Treatment of European Court of Human Rights Case Law: Beyond Compliance}

\author{
Veronika Bílková*
}

\begin{abstract}
Abstrakt
Tento text oceňuje prinos kniby Domestic Judicial Treatment of European Court of Human Rights Case Law: Beyond Compliance (KOSAR, D. et al. Routledge, 2020), a to zejména jako prípadové studie poživáni judikatury Evropského soudu pro lidská práva českými vrcholnými soudy. Poukaruje však na to, že autori svij prispèvek k poznáni v některých aspektech ne zcela vysvétlili. Upozorñuje také na nèketerá zjištèni kniby, kterým by prospèla propracovanèjši argumentace a presvédčivéjši propojeni mezu daty a závèry z. nich vyvozovanými.
\end{abstract}

Klíčová slova

Compliance; Evropský soud pro lidská práva; vrcholné soudy; Evropská úmluva pro lidská práva; prípadová studie.

\begin{abstract}
This article acknowledges the contribution of the book Domestic Judicial Treatment of the European Court of Human Rights Case Law: Beyond Compliance (KOSAR̆, D. et al. Routledge, 2020), especially when read as a case study of the use of the European Court of Human Rights' case law by Czech apex courts. It points out, however, that the authors do not fully explain its contribution to current knowledge. The article also draws attention to some of the book's findings, which would benefit from more elaborate argumentation and more convincing linkages between the data and the conclusions drawn from them.
\end{abstract}

\section{Keywords}

Compliance; the European Court of Human Rights; Apex Courts; the European Convention on Human Rights; Case Study.

Ve své úvaze o stavu oboru mezinárodních vztahů v České republice vydané již před skoro dvěma desítkami let rozlišil český politolog Petr Drulák tři modely rolí, které mohou sehrávat čeští vědci ve vztahu k disciplíně. Jedná se o roli šerpy, kdy je český

\footnotetext{
* Doc. JUDr. Veronika Bílková, Ph.D., E.MA, Ústav mezinárodních vztahů a Právnická fakulta, Univerzita Karlova, Praha / Institute of International Relations and Faculty of Law, Charles University, Prague, Czech Republic / E-mail: bilkova@iir.cz / ORCID: 0000-0002-6298-9630 / Research ID: 57219982351
} 
vědec „ǔ̌itečný coby prưvodce po vlastní zemi“, roli kolegy, s nímž ,lže konzultovat i ty nejsložitějš́ otázkyy, které se v oboru řeši“", ${ }^{2}$ a konečně roli mistra, který „klade nové otázky a obor mèni “" ${ }^{3} \mathrm{~V}$ o několik let mladším článku Drulák jako národní strategii vývoje oboru doporučil všechny tři modely tvưrčím způsobem zkombinovat a „reflexi české mequinárodněpolitické zkušenosti prispivat jak ke svètovému oboru [mezinárodních vztahů], tak $i$ k praxi českých i jiných aktérü". Ačkoli toto doporučení nebylo určeno představitelům české právní nauky, kniha Domestic Judicial Treatment of European Court of Human Rights Case Law: Beyond Compliance ${ }^{5}$ jakoby byla určitým pokusem uvést jej, byt' v rámci jiného oboru, v život. Kniha kombinuje model šerpy, který staví na znalosti konkrétního národního prostředí, s modelem kolegy, jenž nejen přejímá, ale i kriticky reflektuje teoretické přístupy zavedené v hlavním proudu oboru. Místy se zde objevují i snahy stát se mistrem a aktivně ovlivnit další směřování tohoto proudu, a ačkoli v této roli autoři nevystupují zdaleka tak jistě a přesvědčivě jako v předchozích dvou, sama ambice, pro české právní prostředí netypická, patří k hlavním pozitivưm knihy.

Mezi další pozitiva se řadí již povaha díla. Jedná se o skutečnou kolektivní monografii, na jejímž vzniku se podílelo celkem šest hlavních autorů (David Kosař, Jan Petrov, Katarína Šipulová, Hubert Smekal, Ladislav Vyhnánek a Jozef Janovský). Ačkoli je z úvodu knihy i z odkazů v ní uvedených zřejmé, že většina kapitol navazuje na dříve vydané publikace jednotlivých autorů či skupin autorů, samotný text tuto skutečnost nijak výrazněji neodráží. Působí koherentně a stylově jednotně, jak by tomu u kolektivní monografie mělo být - a jak tomu, a to nejen v českém prostředí, bývá jen zřídka. Toho jsou si ostatně autoři vědomi, nebot' sami uvádějí, že jednotlivé části mají „tvorìt celek, nikoli jako kapitoly editovaného souboru spojeného určitými tématy, ale jako kapitoly monografie s jednim autorem" (s. xi). Takto stanoveného cíle je nepochybně dosaženo. Skutečnost, že kniha vznikla za účasti několika autorů a že do její přípravy byly podle uznání v úvodu zapojeny ještě některé další osoby, stojí rovněž za zmínku. Česká právní nauka, přinejmenším v oblasti mezinárodního a ústavního práva, je tradičně spíše individuální než kolektivní „sportovní disciplínou“. Ačkoli první přístup má své výhody, je dobře, že jej v poslední době, z velké části právě díky produkci brněnského Ústavu pro otázky soudnictví, doplňuje př́stup druhý. Schopnost vědecké spolupráce patří mezi důležité akademické dovednosti (ve smyslu ,skills“) a její význam, i vzhledem k trendu pojímat témata interdisciplinárně, poslední dobou dále posiluje.

1 DRULÁK, Petr. Mezinárodní vztahy - časopis a disciplína. Mezinárodní v₹taby, 2001, č. 1, s. 6.

2 Ibid.

3 Ibid.

4 DRULÁK, Petr. Přestaňme dohánět, začněme tvořit! Budoucnost českého oboru mezinárodních vztahů. Mezinárodni vžtaby, 2009, č. 3, s. 104.

5 KOSAŘ, David, Jan PETROV, Katarína ŠIPULOVÁ, Hubert SMEKAL, Ladislav VYHNÁNEK a Jozef JANOVSKÝ. Domestic Judicial Treatment of European Court of Human Rights Case Law: Beyond Compliance. Abingdon: Routledge, 2020. 
Interdisciplinarita je dalším pozitivním rysem monografie, který je třeba zmínit. Ačkoli jsem zatím knihu označovala za součást české právní nauky, ve skutečnosti ji nelze takto jednoduše a jednoznačně ,zaškatulkovat“. Kniha v sobě kombinuje postupy, které známe spíše z právní literatury (nap̌r. popis a analýza soudních rozhodnutî), s postupy, na něž jsme běžněji navyklí z oblasti sociálních věd (zkoumání vlivu složení soudů na jejich rozhodovací praxi, posuzování dopadů soudních rozhodnutí na společnost aj.). To, že text i po této stránce působí koherentně, svědčí nejen o tom, že se autorům podařilo jednotlivé postupy propojit, ale i o tom, že oddělování těchto postupů a snaha o jasné disciplinární rozhraničení nejsou přiliš účelné. Stejně málo účelné jsou, jak je z textu zjevné, spory o to, zda je právo vhodnější zkoumat za pomoci metod kvalitativních, či kvantitativních. Monografie dobře ukazuje, že obě kategorie metod mají svá pozitiva i své limity a že volba mezi nimi v rámci konkrétního výzkumu se primárně odvijí od cílů, které si tento výzkum stanoví. Kniha také ilustruje, jaké cíle je možno dosáhnout a jaké typy otázek lze zodpovědět za využití kvantitativních metod výzkumu, jež jsou zatím v českém právním i sociálně vědním prostředí méně známé a řídčeji využívané.

Zvolená metodologie zčásti určuje strukturu monografie. Ta sestává z úvodu a tř́ částí, které zahrnují jednu či více kapitol. V úvodu autoři vysvětlují, čím, proč, jak a kde se chtějí zabývat. Na otázku „čím“ je odpověd” zdánlivě dána již v názvu monografie, který mluví o nakládání s judikaturou Evropského soudu pro lidská práva (dále ESLP) vnitrostátními soudy. Název ovšem vyžaduje dvě specifikace. První se týká pojmu nakládání (treatment). Tím autoři rozumějí jednak to, zda (a v jaké míře) vnitrostátní soudy judikaturu ESLP citují, a jednak to, v jakém kontextu a za jakým účelem tak činí. Důraz je kladen na vztah mezi vnitrostátními soudy a ESLP, nikoli na dopady soudních rozhodnutí, at' už rozhodnutí vnitrostátních soudů či ESLP, v reálném životě společnosti. Ačkoli autoři vyjadřují důvěru v to, že ,z dloubodobébo blediska mưže impuls vžešlý z judikatury ESLP, prijatý vrcholnými vnitrostátnimi soudy a později sírený do nižšich úrouni soudni hierarchie a následně akceptovaný exekutivou a legislativou, prinést sociálni żěnu" (s. 64), bližší pozornost tomuto procesu nevěnují. Kniha je tak soustředěna na dialog, resp. monolog a jeho následování, v rámci soudní moci.

Přesněji řečeno - a v tom spočívá druhá specifikace názvu, kterou je třeba provést kniha se nezaměřuje na soudní moc jako celek, ale zkoumá interakce, resp. reakce na judikaturu ESLP ze strany úzkého okruhu vrcholných vnitrostátních soudů, a to ještě v jednom konkrétním státě, v České republice. Autoři tento omezený záběr, který by měl být $\mathrm{v}$ názvu knihy aspoň naznačen (nabízelo by se nahrazení nepř́liš vypovídajícího podtitulu „,beyond compliance“ výstižnějším výrazem, např. „the case of the Czech Republic "), zdůvodňují tím, že ,vrcholné soudy [...] jsou aktéri typicky identifikovaní jako nejprominentnèjš̀ prostrednici mezi mez̧inárodnimi lidskoprávnimi soudy a vnitrostátním soudnictvím“ (s. 5). Př́padová studie zaměřená na ČR tak podle jejich názoru „mưže napomoci pochopeni role a postaveni vnitrostátnich soudu v režimu EÚUL, nebot' české soudy po transformaci 
z. nedemokratického režimu čelily výzvě privyknout si pracovat s judikaturou ESLP“ (s. 7). Obě tvrzení jsou nepochybně pravdivá, je ale otázka, nakolik odrážejí zaměření a cíle práce. Vrcholné soudy sice jistě jako prostředníci mezi soudy mezinárodními a národními sloužit mohou, kniha ale této jejich prostřednické roli velkou pozornost nevěnuje. Jak již bylo řečeno, důraz je kladen na vztah, který vrcholné soudy ČR zaujímají vưči judikatuře ESLP, ne na to, jaký vliv v této oblasti vykonávají v rámci národní soudní soustavy. Ačkoli jistě existují dobré důvody předpokládat, že takový vliv existuje, kniha sama nad rámec tohoto předpokladu nejde. Právě zúžení záběru práce jen na vrcholné soudy může být pro čtenáře, i s ohledem na široký název („,domestic judicial treatment“) knihy, určitým zklamáním, byt' lze jistě pochopit praktické důvody, které k němu vedly (mj. velké množství a horší dostupnost rozhodnutí soudů nižší instance).

Zklamáním, byt' tentokrát spíše pro zahraniční než české čtenáře, může být i zaměření výlučně na Českou republiku. Zde práce naráží na úskalí, jimž čelí velká část jednopř́ipadových studií. Na jedné straně si tyto studie již našly v sociálně vědním výzkumu své pevné místo a dříve zastávaný postoj, podle nějž „zjednoho př́padu nelze zobecñovat a cílem sociálnich vèd je poskytovat teoreticky uchopitelná zobecňování. Prípadové studie maji tedy s védou jen málo společného", je již většinově považován za překonaný. $\mathrm{Na}$ druhou stranu podléhá tvorba takových studií poměrně jasným požadavkům, a to už pokud jde o volbu vhodného př́padu. Tato volba by neměla odrážet jen výše popsaný model šerpy, tj. určitý př́pad by neměl být vybrán jen proto, že autoři mají komparativní výhodu v přístupu k informacím a datům, které se jej týkají, např. na základě jazykové vybavenosti. Měla by naopak reflektovat modely kolegy či dokonce mistra, tj. případová studie by měla umožnit potvrdit, korigovat či zpřesnit určitou existující obecnější teorii, popř. vést k formulaci takové teorie nové. Z knihy je zjevné, že autoři jsou si této skutečnosti vědomi a že mají ambice předložit více než jen zajímavou národní studii. Než se zamyslíme nad tím, nakolik se jim to daří, je třeba zmínit se ještě o některých dalších parametrech knihy.

To, čím a kde se autoři zabývají, již bylo uvedeno. Zbývá ono proč a jak, tj. jaké cíle kniha sleduje a za pomoci jakých metod a postupů tak činí. Cílem knihy v nejširším smyslu je popsat a zanalyzovat roli (některých) vnitrostátních soudů při implementaci rozhodnutí ESLP. V užším pojetí usilují autoři o doložení argumentu, podle nějž ,je štrasburský soud prirozueným spojencem pro nově vanikelé (zulástě ústavní) soudy v transformujicich se demokraciích" (s. 8). Vnitrostátní soudy slouží jako šiřitelé norem (norm-diffusers), kteří prostřednictvím práce s judikaturou ESLP i spíše „ornamentálních“ odkazů na ni postupně transformují národní právní řád a národní právní kulturu. Způsob a míra, v jaké to dělají,

6 Cit. in KOŘAN, Michal. Jednopř́padová studie. In: DRULÁK, Petr (ed.). Jak ₹koumatpolitiku. Kvalitativní metodologie v politologii a mezinárodnich vžtazich. Praha: Portál, 2008, s. 29; Srov. LINOS, Katerina. How to Select and Develop International Law Case Studies: Lessons from Comparative Law and Comparative Politics. American Journal of International Law, 2015, roč. 109, č. 3, s. 475-485. DOI https://doi. org/10.5305/amerjintelaw.109.3.0475 
je u různých soudních orgánů různá a mění se také, tentokrát i u jednotlivých orgánů, v čase. Konstantní zůstává to, že vnitrostátní soudy málokdy prímo zpochybňují autoritu a legitimitu ESLP a spíše mají tendenci vymezovat se vưči konkrétním rozhodnutím, nikoli obecnému postavení a směřování tohoto orgánu. Autoři uvádějí, že takto postavený argument se týká nejen České republiky, ale je „aplikovatelný mimo českou prípadovou studii“ (s. 8). Z textu bohužel není jasné, o co je tento názor opřen. Co př̀esně autory vede k závěru, že poznatky získané detailním výzkumem činnosti tři českých soudních institucí jsou bez dalšího přenositelné na instituce jiné? A o jaké jiné instituce se má jednat? O vrcholné, nebo i jiné, soudy v zemích procházejících transformací k demokracii, jak naznačuje výše uvedený odkaz na „transformující se demokracie“? Nebo o vnitrostátní soudy, at' již vrcholné, či všechny, obecněji?

Kniha jasné odpovědi na tyto otázky nedává a celkově se zdá, že autoři její hlavní př́nos nespatřují ani tak, nebo přinejmenším pouze, $v$ substantivních argumentech jako spíše v metodě výzkumu. Přesněji řečeno jde o metodu, resp. metody, jež jsou uplatněny ve druhé části knihy, tedy v části, která obsahuje českou př́padovou studii. Tato část se konkrétně věnuje judikatuře Nejvyššího soudu, Nejvyššího správního soudu a Ústavního soudu, přičemž ve všech případech je tato judikatura zkoumána na třech rovinách. První je makro-rovina, kde autory zajímá, v jaké míře vnitrostátní soudy citují rozhodnutí ESLP a o jaká rozhodnutí se nejčastěji jedná. Zjišt'ují to za pomoci automatizované textové analýzy (automated text analysis) aplikované na soubor rozhodnutí z období od vzniku př́slušného soudu do roku 2015. Druhou rovinou je mezo-rovina. Zde je předmětem zájmu to, jak vrcholné soudy s judikaturou ESLP pracují, tedy např. nakolik ve svých rozhodnutích staví na této judikatuře a v jakých př́padech, pokud vůbec, se vưči ní vymezují kriticky. Mezo-rovina pracuje se čtyřmi soubory kategorií, které jsou sice prezentovány jako jasně a jednoduše oddělitelné (viz tabulka na s. 95), reálně se ale mohou prostupovat a navíc kritéria zařazení do nich nejsou z textu zcela zřejmá. Z toho též vyplývá, že analýza na mezo-rovině vyžaduje značnou míru kvalitativního posouzení a nejde o věc čistě mechanické kategorizace, jak by se z využitých kódů a na nich vystavených tabulek a grafů mohlo zdát. Poslední, třetí rovinou je mikro-rovina. Na ní autoři přistupují ke zhodnocení toho, jak se vnitrostátní soudy vyrovnávají s judikaturou ESLP v konkrétních kauzách či oblastech úpravy. Toto zhodnocení, realizované cestou klasické právní analýzy, bude českému právnímu prostředí asi nejbližší a nejpovědomější.

Rozlišení tří rovin analýzy autoři označují za "novátorské“ (s. 12), „inovativni" (s. 57), „jdoucí nad rámec existujicího stavu poznáni" (s. 56) atd. Kladná (sebe)hodnocení prrístupu se v úvodu a první části knihy objevují natolik často a slibují tak výraznou revoluci ve výzkumu, že když je pak čtenář s aplikací přístupu reálně konfrontován, může prožít určité zklamání. Za skutečně nové lze považovat pojmenování jednotlivých rovin a aplikaci př́stupu na národní prrípadovou studii. Naopak samo využití jak kvantitativních, tak kvalitativních metod v rámci právní nauky, včetně výzkumu implementace 
mezinárodních závazků, je již poměrně zaběhlé. ${ }^{7}$ Obdobně tak úplně neplatí, že „není mnoho známo o tom, jak národni soudy zacházeji s mezinárodni judikaturou" (s. 57). Tomuto tématu je naopak v posledních letech věnována značná pozornost a vyšly k němu přinejmenším desítky článků a jiných výstupů. ${ }^{8}$ Je škoda, že autoři tuto literaturu reflektují jen omezeně a že podrobněji nevysvětlují, právě na základě konfrontace s existující literaturou, v čem přesně existuje ona mezera ve výzkumu, kterou mají ambici zaplnit.

Práce s existující literaturou si zaslouží ještě dva komentáře. První se týká výběru této literatury, druhý způsobu, jakým s ní autoři nakládají. Ohledně výběru text zaujme mírou auto-referenčnosti. Je jistě standardní, že autoři vycházejí z textů, které oni nebo jejich kolegové k tématu publikovali. Méně standardní už je, když tyto texty v mnoha úsecích včetně těch, kde jsou dostupné zdroje jiné provenience, tvoří hlavní referenční rámec. Navíc, což již souvisí se způsobem nakládání s literaturou, odkazy na využité texty obvykle nejsou doplněny alespoň stručným představením toho, co dané texty přinášejí. Jakoby autoři předpokládali, že čtenáři jejich produkci zkrátka musejí znát, a že tak postačí zařadit do textu pouhý odkaz a bude jasno. Trochu podrobněji pojednávají autoři o textech jiných autorů, na něž navazují, popř. vưči nimž se vymezují, zejména v obecných částech knihy. Jejich prrístup $\mathrm{v}$ těchto př́padech ale $\mathrm{v}$ mnoha ohledech odpovídá schématu, které by se dalo popsat jako „př́liš mnoho pro jedny, prríliš málo pro druhé“. Pro ty, kteří jsou s odbornou literaturou v prríslušné oblasti seznámeni, nenabízí její přehled a stručná charakteristika nic nového - to je ono př́liš mnoho. Naopak ti, kteří s ní seznámeni nejsou, se o ní z knihy nedozvědí tolik, aby jim to dalo jasnější představu o stavu poznání - to je ono př́liš málo. Tento přístup, který zvláště zamrzí v pasážích věnovaných obecným konceptům (kapitoly 2 a 3), kontrastuje s mírou detailů a mírou opakování, které nalezneme v jiných pasážích (nap̌r. ony tři roviny analýzy jsou v knize, v podstatě stejným způsobem, uvedeny hned několikrát).

Určitá nevyrovnanost se projevuje také v předkládání závěrů výzkumu. Kniha je silnější a presvědčivější při prezentaci faktů a dat než při snahách o jejich vysvětlování

7 Viz např. ŠADL, Urška a Henrik Palmer OLSEN. Can Quantitative Methods Complement Doctrinal Legal Studies? Using Citation Network and Corpus Linguistic Analysis to Understand International Courts. Leiden Journal of International Law, 2017, roč. 30, č. 2, s. 327-349; ALSCHNER, Wolfgang, Joost PAUWELYN a Sergio PUIG. The Data-Driven Future of International Economic Law. Journal of International Economic Law, 2017, roč. 20, č. 2, s. 217-231. DOI https://doi.org/10.1093/jiel/jgx020; SLAUGHTER, Anne Marie, Alec STONE SWEET a Joseph WEILER (eds.). The European Court and National Courts: Doctrine \& Jurisprudence: Legal Change in its Social Context. Hart, 2003.

8 Srov. např. NOLLKAEMPER, André a August REINISCH (eds.). International Law in Domestic Courts: A Casebook. Oxford University Press, 2019; TZANAKOPOUlOS, Antonios. Domestic Courts in International Law: The International Judicial Function of National Courts. Loyola of Los Angeles International and Comparative Law Review, 2011, roč. 34, s. 133-168; ALAM, Shah M. Enforcement of International Human Rights Law by Domestic Courts: A Theoretical and Practical Study. Netherlands International Law Review, 2006, roč. 53, č. 1, s. 399-438. DOI https://doi.org/10.1017/ S0165070X06003998; KIRBY, Michael. Domestic courts and international human rights law The ongoing judicial conversation, Utrecbt Law Review, 2010, roč. 6, č. 1, s. 168-181. 
a zobecňování. V první oblasti se autoři opírají o dobře propracovanou metodologii kvantitativní analýzy dat a kvalitativního rozboru př́ípadů. Ve druhé se naopak nezřídka uchylují $\mathrm{k}$ postupům, jež mohou vyvolávat pochyby. Čtenářrum je nabídnuto určité vysvětlení, teze či argument, které sice nejsou v knize ničím prrímo doloženy, autoři je ale bud' prezentují jako dané a zjevné, nebo je vyvozují ze svého a priori hodnocení určitých jevů či institucí, nebo, konečně, př́i jejich „dokládání“ odkazují na svou osobní zkušenost. Př́rkladem (údajně) daného a zjevného je soubor argumentů, které jsou předloženy v kapitole 8. Zde se mj. dozvíme, že „české vrcholné soudy významně prìspěly k všeobecně uspokojivému výsledku, pokud jde o dodržováni Úmluvy a respektováni interpretace štrasburskébo soudu“, (s. 217) a že „rozširováním informaci vrcholné soudy prispivaji k respektování judikatury ESLP że strany nižžich soudü“(s. 218). Obě tvrzení mohou být pravdivá. V knize ale není nic, co by tuto pravdivost dokládalo. Jak již bylo řečeno, kniha se interakcemi mezi vrcholnými vnitrostátními soudy a soudy nižší instance, potažmo dalšími státní orgány, nezabývá. Je pak otázkou, nakolik je moudré předkládat, ještě v části obsahující závěry výzkumu, tvrzení, která spadají do oblasti mimo rámec tohoto výzkumu.

Druhý sporný postup se odvijî́ od určitých a priori postojů, které autoři zastávají (což by nevadilo) a které místy poměrně silně ovlivňují jejich výklad faktů a dat (což již vadit může). Jako přiklad lze uvést to, že kniha má své kladné a méně kladné hrdiny, přičemž autoři prezumují, že tito hrdinové musejí být ve svém jednání vedeni odlišnými motivy a to i za situace, kdy dělají věci totožné nebo velmi podobné. Kladnými hrdiny jsou vedle ESLP Ústavní soud a Nejvyšší správní soud. ESLP v knize vystupuje jako moudrý učitel, který ví, o čem mluví, a prakticky nikdy se neplete. Oba vnitrostátní soudy vystupují coby v zásadě poslušní žáci, kteří učiteli pozorně naslouchají, a pokud se výjimečně neř́ídí přesně tím, co jim učitel řekl, mají pro to jistě dobré důvody. Méně kladným hrdinou a zlobivějším žákem je Nejvyšší soud. I ten sice učiteli vcelku naslouchá a nenásleduje ho jen výjimečně, pokud už tak ale činí, má k tomu nepochybně důvody méně dobré než jeho spolužáci. Stejně jako v předchozím případě platí, že toto chápání může být správně. Platí ale opět i to, že tuto správnost nemưže čtenář př́liš posoudit, protože až na pár neuctivých poznámek na adresu ESLP ze strany zástupců Nejvyššího soudu a některých obecných hypotéz (starší soudní instituce musí být EÚLP méně nakloněná než instituce novější apod.) autoři nepředpokládají nic, co by mu to dovolilo. Přesněji řečeno nabízejí, a to svou vlastní zkušenost a „vnitřní znalost“(s. 216) fungování soudních orgánů v ČR. Ačkoli o této zkušenosti a znalosti není důvod pochybovat, ani tento třetí, přece jen poměrně individuální a subjektivní postup nemusí být pro čtenáře nutně zcela přesvědčivý.

Když bychom se nyní vrátili $\mathrm{k}$ modelům nastíněným $\mathrm{v}$ úvodu této stati a $\mathrm{k}$ míře, $\mathrm{v}$ jaké kniha naplňuje stanovené cíle, bylo by možno konstatovat, že autoři velmi dobře obstáli v modelu šerpy. Kniha je důkladně zpracovanou a o pečlivě sesbíraná a zpracovaná data opřenou národní jednopřípadovou studií, která dokládá, že vrcholné soudy 
v České republice pracují s judikaturou ESLP a že tuto judikaturu sice využívají v závislosti na potřebách daných domácím prostředím a řešenými kauzami, celkově se $\mathrm{k}$ ní, a zejména $\mathrm{k}$ ESLP samotnému, ale staví vstřícně a v podstatě nekriticky. Interakce mezi ESLP (učitel) a vrcholnými českými soudy (žáci) tak má spíše podobu klasické frontální výuky než interaktivního semináře, což autoři zjevně vnímají jako pozitivum. ESLP a vrcholné vnitrostátní soudy jsou pro ně na jedné lodi, jsou to, jak je v knize opakovaně uvedeno, prrirození, byt' ne rovní, spojenci, přičemž se předpokládá, že pokud toto spojenectví funguje, zákonitě to musí vyvolat rozsáhlejší právní, sociální a politické změny v př́slušné zemi. Díky šerpovské úloze, které se autoři ujali, můžeme říci, že i když ony rozsáhlejší změny zůstávají mimo zájem knihy, samotné spojenectví ESLP a vrcholných vnitrostátních soudů je na české př́ípadové studii zdokumentováno a doloženo velmi podrobně a přesvědčivě. O tom, že české vrcholné soudy využívají judikaturu ESLP, nemůže mít nikdo, kdo si monografii přečte, pochyby.

Spornější otázkou je, zda kniha nabízí obecnější poznatky, jež by byly využitelné mimo př́padovou studii, a nakolik se tedy autorům podařilo vymanit $z$ modelu šerpy a stát se kolegy, či dokonce mistry. Ambice v tomto směru autoři, jak bylo řečeno, nesporně měli. Tyto ambice se, jak již také bylo řečeno, týkaly jednak metod výzkumu, jednak některých jeho věcných závěrů. Pokud jde o metody výzkumu, resp. o využití tzv. tří rovin analýzy, lze mít za to, že autoři sice nepřicházejí se zcela „novou metodologii pro výzkum chování soudü“(s. 4), jak v knize tvrdí, užitečně ale rozpracovali metodologie již existující a zavedli nové kategorie a nová označení, která mohou výzkum učinit přehlednějším. V tomto ohledu si počínali jako zkušení kolegové, kteří se dokáží úspěšně zapojit do hlavního proudu výzkumu v určité oblasti a vnášejí do tohoto výzkumu vlastní vylepšení. Totéž do určité míry platí ve vztahu k věcným závěrům výzkumu, byt' zde je posouzení přínosu o něco těžší. Těžší už proto, že tyto závěry jsou v různých částech knihy prezentovány poněkud odlišně. Zatímco úvod staví na tezi o přirozeném spojenectví ESLP a vrcholných vnitrostátních soudů a významu tohoto spojenectví při transformaci k demokracii (s. 8), shrnující kapitola opřená o českou prrípadovou studii klade důraz na roli vrcholných soudů při zajišst'ování respektu k EÚLP na národní úrovni (s. 217). Obě teze spolu souvisejí, nelze ale mít za to, že by byly zcela totožné.

Ještě výraznější obrat přináší poslední část knihy (kapitola 9), která opouští tematický, argumentační i geografický rámec, v němž se autoři dosud pohybovali, a nově obrací pozornost k širšímu hodnocení vlivu, jaký mohou mít aktivity vrcholných vnitrostátních soudů a jejich zacházení s judikaturou ESLP na právní, sociální a politické změny v určité zemi. Hodnocení se přitom neomezuje na Českou republiku, ale zaměruje se, poněkud překvapivě, i na další státy střední a východní Evropy, jejichž fungování a judikatura ovšem nebyly v knize podrobeny žádnému zkoumání. Autoři si z této judikatury cíleně vybírají kauzy, jež mají dokumentovat, že vrcholné vnitrostátní soudy nemusejî být jen oněmi kladnými či méně kladnými hrdiny, jimiž se ukázaly být soudy české, 
ale mohou se stát rovněž padouchy, kteří používají judikaturu ESLP k temným účelům. V knize bohužel chybí úvaha nad tím, jak tato role zapadá do argumentu o přirozeném spojenectví ESLP a vrcholných soudů a nakolik vrhá pochyby na možnost vyvodit z české prrípadové studie obecnější závěry. Závěrečné tvrzení autorů, podle nějž „vrcholné soudy už možná prírozeným domácím spojencem ESLP nejsou. Naopak, mohou se stát blavni prékážkou implementace štrasburských standardů a centra odporu proti ESLP“ (s. 251), lze těžko číst jinak než jako uznání toho, že ona možnost zobecnění je dosti omezená. Zařazením kapitoly 9, která sice zapadá do současných debat o tzv. úpadku vlády práva (rule of law backsliding), v knize ale působí cizorodě, tak autoři do značné míry podkopali úsilí, jež vložili do předchozích částí knihy, a dali si pomyslný gól do vlastní branky.

Již délka této úvahy naznačuje, že navzdory dílčím výhradám, které lze vưči některým aspektům monografie mít, se jedná o velmi zajímavý, ambiciózní a podnětný výzkumný počin, který jistě v českém a mezinárodním prostředí vyvolá mezi akademiky i praktickými právníky velký zájem a živou debatu. Kniha sice může část zahraničních čtenářu odradit zaměřením na Českou republiku a část čtenářu českých naopak zvoleným jazykem (angličtina), většina zájemců o téma ale nepochybně ocení jak poctivost a důkladnost výzkumu, na němž kniha staví, tak snahu autorů zasadit českou prrípadovou studii do širšího teoretického a metodologického rámce. Porozumění tomuto rámci i závěrům výzkumu navíc usnadňují různé grafy, tabulky a schémata, které autoři do práce zařadili a jež jsou prŕijemným a užitečným doplňkem ne vždy snadno prrístupného textu. Ačkoli monografie neprrináší do výzkumu interakcí mezi ESLP a vrcholnými vnitrostátními soudy, resp. výzkumu vztahu mezinárodních a vnitrostátních soudních orgánů vědeckou revoluci, ${ }^{9}$ je pro tento výzkum cenným obohacením. Současně může sloužit jako dobrá ilustrace toho, že přinejmenším někteří čeští právníci se již dávno nespokojují s rolí šerpy, jenž díky své znalosti místního prostředí může druhým pomáhat při cestě vzhůru, ale počínají si jako sebevědomí a rovní kolegové, kteří s druhými na onu cestu vyrážejí bok po boku. A mají dokonce ambice druhé, coby mistři, při stoupání vést.

9 Srov. KUHN, Thomas S. Struktura védeckých revolucí. Praha: Oikoymenh, 2008. 